\title{
Turizmde Algılanan Değer Kavramı: Çok Boyutlu Algılanan Değer Ölçeğinin Destinasyonda Uygulanabilirliği
}

\section{The Concept of Perceived Value in Tourism: A Research on The Applicability of The Multidimensional Perceived Value Scale in Destination}

\author{
Muammer BEZIRGAN ${ }^{\text {** }}$ \\ *Dr. Öğr. Üyesi, Balıkesir Üniversitesi, Burhaniye UBYO, Gastronomi ve Mutfak Sanatları Bölümü, Balıkesir/Türkiye \\ ORCID: 0000-0002-6562-539X
}

\section{MAKALE BILGGISI}

\section{Makale Geçmişi:}

Başvuru tarihi: 01 Ocak 2019

Düzeltme tarihi: 25 Şubat 2019

Kabul tarihi: 07 Mart 2019

\section{Anahtar Kelimeler:}

Destinasyon,

Algilanan değer,

Kemer,

Antalya

\section{ARTICLE INFO}

\section{Article history:}

Received 01 January 2019

Received in revised form 25 February 2019

Accepted 07 March 2019

\section{Keywords:}

Destination,

Perceived value,

Kemer,

Antalya

\section{ÖZ}

Bu çalışmada turizm ve diğer hizmet sektörlerine yönelik geliştirilip kullanılan çok boyutlu algılanan değer ölçekleri derinlemesine incelenmiş ve turizm destinasyonu bağlamında turistlerin destinasyondan algıladıkları değer faktörlerinin neler olduğu tespit edilmeye çalışılmıştır. $\mathrm{Bu}$ amaçla Antalya ili Kemer ilçesinde tatil yapan turistler üzerinde bir uygulama gerçekleştirilmiştir. 414 turistten elde edilen veriler istatistiksel analiz programları kullanılarak analiz edilmiştir. Çalışmada algılanan değer boyutlarının neler olduğunun belirlenmesinde açıklayıcı ve doğrulayıcı faktör analizlerinden yararlanılmıştır. Araştırma sonuçları incelendiğinde, destinasyondan algılanan değer ölçeğinin çok boyutlu yapıda ve duygusal değer, fiyat değeri, şöhret değeri, davranışsal değer, kalite değeri ve ulaşım değeri olmak üzere altı boyuttan oluştuğu tespit edilmiştir. Ayrıca litaretürde farklı alanlarda yapılan çok boyutlu algılanan değer çalışmalarıyla benzerlikler taşıdığ 1 ve destinasyona uygulanabilirliğinin istatistiksel olarak geçerli olduğu tespit edilmiştir.

\section{A B S T R AC T}

The present study aimed to investigate the multidimensional perceived value scales developed and used in tourism and other service industries in depth and to determine the value factors perceived by the tourists about a destination within the context of tourism destinations. For this purpose, an application was conducted on the tourists holidaying in the Kemer district of Antalya province in Turkey. Data collected from 414 tourists were analyzed using statistical analysis software. In the study, explanatory and confirmatory factor analyzes were used to determine the perceived value dimensions. The study findings demonstrated that the destination perceived value scale was multidimensional and included six dimensions of emotional value, price value, reputation value, behavioral value, quality value and transportation value. Furthermore, it was determined that the scale was consistent with multidimensional perceived value studies conducted in different fields in the literature and its applicability to the destination was statistically valid.

\section{Giriş}

Son yıllarda seyahat alışkanlıklarının değişmesi ve turizm bilincinin artmasıyla beraber Dünyada ve Türkiye'de insanların seyahat sayıları artış içerisindedir. Eskisine oranla daha fazla turistin yer aldı̆̆ 1 pazarda destinasyonlar ekonomik, sosyal ve kültürel gelişimleri için turizm sektörüne önem vererek destinasyon pazarlamasına yönelmektedirler. Ulaşım imkanlarının artmasıyla bir çok destinasyon sahip olduğu turizm potansiyelini kullanarak pazarda rekabetin artmasına yol açmaktadır. Fiziksel çekicilikleri birbirine benzeyen ancak sunulan mal ve hizmetin kalitesini arttırarak turistlere değer yaratan destinasyonlar ciddi oranda rekabet avantajı elde edebilme şansına sahip olmaktadırlar. Çünkü turistik ürünün kendine özgü yapısından dolayı fiziksel çekiciliklerin değiştirilmesi çok mümkün değildir. Son yıllarda rekabetçiliğin üst seviyede olduğu pazarlarda değișen tüketici profili ve

\footnotetext{
** Sorumlu yazar/Corresponding author

e-posta: muammerbezirgan@hotmail.com
} 
birbirine benzeyen ürünlerin sayıca çoğalması ile birlikte tüketici açısından kendisine değer yaratan faktörlerin ön plana çıktığı görülmektedir.

$\mathrm{Bu}$ araştırmanın amacı literatürde algılanan değer kavramı üzerine yapılan çalışmaları incelemek, çok boyutlu algılanan değer ölçeklerinin turistik destinasyon boyutunda uygulanabilirliğini saptamak ve destinasyon boyutunda çok boyutlu algılanan değer ölçeğinin geliştirilmesine katkı sağlamaktır. Algılanan değerin kavramlaştırılmasına yönelik ilk çalışmalarda daha çok tüketicilerin sanayi ürünlerine yönelik değer algılamaları üzerinde durulmuştur (Sheth ve diğ., 1991; Zeithaml 1988; Katamneni ve Coulson, 1996; Sweeney ve Soutar; 2001). Daha sonraki y1llarda ilk olarak Petrick (2002) tarafından yapılan bir çalışma ile hizmetlere ilişkin olarak algılanan değer ölçeği (Serv-Perval) geliştirilmeye çalışılmıştır. Turizm alanında algılanan değer ile ilgili ilk kapsamlı çalışma ise Sanchez ve diğerleri (2006) tarafından gerçekleştirilen ve ismini Gloval ölçeği verdikleri ölçek çalışmasıdır. Bununla birlikte turizm alanında Sanchez ve diğerleri (2009) tarafından geliştirilen Cvs ölçeği, algılanan değer ile ilgili çok boyutlu ölçek geliştirme çalışmalarından bir diğeridir.

Sanayi ürünlerine yönelik yapılan algılanan değer kavramı çalışmalarında, algılanan değerin, ürün satın alımı öncesinde gerçekleşen bir olgu olduğu üzerinde durulmuştur (Doddsve diğ., 1991; Sweenwy ve diğ., 1997; Grewal ve diğ., 1998; Cronin ve diğ., 2000). Ancak genel olarak hizmetler sektörünün ve hizmetler sektörünün altında yer alan turizm sektörünün kendine özgü hizmet üretim yapısı nedeniyle, turizmde ve özellikle destinasyon boyutunda, algılanan değeri yalnızca satın alım öncesinde değerlendirmek mümkün değildir. Sanchez ve diğerlerine (2006) göre turizm alanında algılanan değer, satın alma sürecini de kapsayan bir yapıya sahiptir. Çünkü turizm ürününün üretimi tatilcinin eve dönüşüne kadar geçen tüm süreci kapsamaktadır.

İlgili alan yazın incelendiğinde özellikle son yıllarda yapılan çalışmalarla birlikte algılanan değer kavramının turizm hizmet üretim süreçlerini de kapsamaya başladığı görülmektedir. Her ne kadar son yıllarda turizm alanında algılanan değer kavramı ile ilgili çalışmalar olsa bile, destinasyon boyutunda kapsamlı bir algılanan değer ölçümü ile ilgili sınırlı sayıda araştırma gerçekleştirilmiştir. Ayrıca algılanan değer ile ilgili turizm alan yazınında çok sayıda çalışma olmasına rağmen sınırlı sayıda çalışmada algılanan değer kavramı çok boyutlu bir yapıda kullanılmıştır (Sweeney ve Soutar, 2001; Petrick, 2002,2004; Sanchez ve diğ., 2006; Gill ve diğ., 2007). Bu çalışmada yazında yer alan bu eksikliğin giderilmesi amaçlanmıştır. Bu sebeple araştırmada destinasyon boyutunda algılanan değer ölçeği literatürdeki çok boyutlu algılanan değer ölçekleri kullanılarak oluşturulmaya çalışılmıştır. Bu amaçla Antalya ili Kemer ilçesinde tatil yapan turistler üzerinde bir uygulama gerçekleştirilmiştir.

\section{Literatür Taraması}

\subsection{Alg1lanan Değer Kavramı}

Bugüne kadar yapılan algılanan değer ile ilgili çalışmalarda kavram ile ilgili birçok farklı isimlendirmenin yapıldığ 1 görülmektedir. Çalışmaların büyük bir çoğunluğunda kavramın algılanan değer olarak ifade edildiği görülmektedir (Konuk, 2008). Algılanan değer kavramını ilk olarak geniş perspektifte ele alan ve tanımlayan Zeithaml (1988)'a göre algılanan değer; ödünlerin ve faydaların karşılaştırması sonucunda ürün ya da hizmet faydasına yönelik genel değerlendirmedir. Algılanan değer tanımlamalarında genel olarak "değer" kavramı tüketicinin edinim ve bedel algılamaları doğrultusunda şekillenen bir değişkendir. Edinim boyutu genel olarak kalite ile ilişkilendirilirken, bedel boyutu genel olarak fiyat ile ilişkilendirilmektedir (Koçak ve Çeşmeci, 2011:233). Yazında değer ile ilgili yapılan tanımlamalar Tablo 1'de sunulmuştur.

Tablo 1. Literatürde Yer Alan Değer Tanımları

\begin{tabular}{|c|c|}
\hline $\begin{array}{l}\text { Monroe, } \\
\text { (1990) }\end{array}$ & $\begin{array}{l}\text { - Değer algısı; alıcının edindiği kalite ve } \\
\text { faydalarla buna karşılı ödediği bedelin } \\
\text { klyaslamasıdır }\end{array}$ \\
\hline Day, (1990) & $\begin{array}{l}\text { - Algılanan müşteri değeri, “müşterinin } \\
\text { algılanan yararları" ve "müşterinin algılanan } \\
\text { maliyetleri" arasındaki farkı temsil eder. }\end{array}$ \\
\hline Gale, (1994) & $\begin{array}{l}\text { - Müsşteri değeri; ilgili ürünün göreli fiyatı ile } \\
\text { kıyaslanan algılanan kalitesidir }\end{array}$ \\
\hline $\begin{array}{l}\text { Woodruff, } \\
\text { (1997) }\end{array}$ & $\begin{array}{l}\text { - Müststeri değeri; müşterilerin bir ürünü } \\
\text { almak veya kullanmak ile edineceklerine } \\
\text { inandıkları veya edinmek istedikleridir }\end{array}$ \\
\hline $\begin{array}{l}\text { Lichtenstein } \\
\text { ve diğ., } \\
(1990)\end{array}$ & - Değer; kalitenin fiyata oranıdır \\
\hline $\begin{array}{l}\text { Dodds ve } \\
\text { diğ. (1991) }\end{array}$ & $\begin{array}{l}\text { - Algılanan değer; kalite ve fedakarlık } \\
\text { algılamaları arasındaki bilişsel takastır }\end{array}$ \\
\hline $\begin{array}{l}\text { Holbrook, } \\
\text { (1996) }\end{array}$ & $\begin{array}{l}\text { - Müssteri değeri; etkileşimli, göreceli tercih } \\
\text { tecrübesidir }\end{array}$ \\
\hline
\end{tabular}

Tabloda yer alan değer tanımlarından da anlaşıldığı üzere değer olgusu fayda ve fiyat olarak iki bileşenden oluşmaktadır. Woodruff'a (1997) göre literatürde yer alan değer tanımlarında bazı ortak noktalar bulunmaktadır:

- Algılanan değer, belirli bir ürün ya da hizmetin kullanımıyla ilişkilidir.

- Algılanan değer tüketiciler (müşteriler) tarafından algilanmaktadır.

- Değer algılaması, genel olarak tüketicilerin ürün ya da hizmeti elde etmek ya da kullanmak için katlandığı ödünler ile üründen sağlanan fayda arasındaki karşılaştırmaya dayanmaktadır.

\subsection{Alg1lanan Değer Boyutları}

Algılanan değerle ilgili yapılmış çalışmalar incelendiğinde algılanan değerin bazı çalışmalarda (Grewal ve diğ. 1998; Dodds ve diğ.1991; Cronin ve di ̌̆. 2000; Gallarza ve Saura, 2006) tek boyutlu bir yap1 olarak ele alındığı, bazı çalışmalarda (Sheth ve diğ., 1991; Katamneni ve Coulson, 1996; Sin ve diğ., 2001; Sweeney ve Soutar, 2001; Petrick, 2002; Sanchez ve diğ., 2006) ise çok boyutlu bir yapı olarak ele alındığı görülmektedir. Fernandez ve Bonillo (2007:442), algılanan değerin tek boyutlu ve çok boyutlu yapıları arasındaki çeşitli farklılıklarını şu şekilde belirlemişlerdir;

- Tek boyutlu yap1 algılanan değere bilişsel bir açıdan yaklaşırken, çok boyutlu yapı bilişselin yanı sıra duygulanım açısından da yaklaşmaktadır.

- Tek boyutlu yapı daha sade ve basitken, çok boyutlu yapı zengin ve karmaşıktır. 
- Tek boyutlu yapı kullanıcıya sadece değerin nasıl değerlendirildiğiyle ilgili bilgileri sunarken, çok boyutlu yap1 değerin nasıl arttırılabilineceğine dair yönlendirmeler sunmaktadır.

- Tek boyutlu yapıyı ele alan araştırmacılar arasında algılanan değerin öncesinde gelen yapıların ne olduğu ile ilgili fikir anlaşmazlığı bulunmaktadır. Çok boyutlu yapıyı ele alan araştırmacılar arasında ise, algılanan değerin boyutlarının ne olduğu ile ilgili fikir anlaşmazlığı bulunmaktadır.

- Alan yazında genel olarak kabul edilen yap1 tek boyutlu yapıdır.

Alan yazında yer alan tek boyutlu değer çalışmaları genellikle fiyat/parasal/maddi değer boyutu ile kullanılmaktadır. Ancak algılanan değer kavramını çok boyutlu olarak ele alan çalışmalarda fiyat değeri çok boyutlu yapının tek bir boyutunu oluşturmaktadır. Fiyat değerinin yanında yazında yer alan algılanan değer boyutları çok çeşitlilik arz etmekle birlikte daha çok sosyal değer, duygusal değer, zaman değeri, fonksiyonel değer ve davranışsal değer boyutları üzerinde yoğunlaşmaktadır. Tablo 2'de alan yazında yer alan çeşitli çalışmalarda kullanılan algılanan değer boyutları yer almaktadır.

Tablo 2. Algılanan Değer Boyutları

\begin{tabular}{ll}
\hline Yazarlar & Algılanan değer boyutları \\
\hline Sheth ve diğ., (1991) & Sosyal değer \\
& Duygusal değer \\
& Fonksiyonel değer \\
& Epimestik değer \\
& Şartli değer \\
\hline Gronroos, (1997) & Bilişsel değer \\
& Duygusal değer \\
\hline De Ruyter ve diğ., (1997) & Duygusal değer \\
& Fonksiyonel \\
& Mantiksal \\
\hline Sweenwy ve diğ., (1997) & Sosyal değer \\
& Duygusal değer \\
& Fonksiyonel değer \\
& Fonksiyonel Değer \\
& Fonksiyonel değer \\
\hline Sosyal değer \\
& Fonksiyonel değer \\
& Duygusal \\
\hline Sweeney ve Soutar, (2001) & Kalite değeri \\
& Duygusal değer \\
& Parasal değer \\
& Davranışsal değer \\
\hline Petrick, (2002) & Ün değeri \\
\hline Sanchez ve diğ., (2006) & Fiziksel fonksiyonel değer \\
& Personelin fonksiyonel değeri \\
& Ürünün fonksiyonel değeri \\
& Duygusal değer \\
& Sosyal değer \\
\hline Fonksiyonel Değer \\
& Deneyimsel/Hedonik değer \\
& Sembolik/Etkileyici değer \\
& Fiyat değeri \\
\hline Etkinlik değeri \\
Kalite değeri \\
Sosyal değer \\
Eğlence değeri \\
Estetik değeri \\
Ruhani değer \\
\hline
\end{tabular}

\section{Araştırmanın Yöntemi}

Turizm alanında çok boyutlu algılanan değer kavramını ölçmeye yönelik olarak gerçekleştirilen çalışmaların büyük bir kısmında Petrick (2002) tarafından geliştirilen ServPerval ölçeği, Sanchez ve diğ. (2006) tarafından geliştirilen Gloval ölçeği ve Sanchez-Fernandez ve Iniesta-Bonillo ve Holbrook (2009) tarafından geliştirilen Cvs ölçeğinin kullanıldığ1 görülmektedir. Ölçekler arası karşılaştırmada Petrick (2002) tarafindan geliştirilen Serv-Perval ölçeğinde ölçeğin açıklama gücü belirtilirken Gloval ve Cvs ölçeklerinde ölçeğin açıklama gücü ile ilgili açık bir bilgilendirme yapılmamıştır. Destinasyon ölçeğinde algılanan değerin ölçülmeye çalışıldığı bu çalışma amacı dikkate alındığında hem ölçek güvenilirliği ve geçerliliği açısından daha açık ifadelerin yer aldığı hem de destinasyona uyarlanabilirliği açısından ise Petrick (2002) tarafindan geliştirilen ölçekte yer alan faktörlerin daha uygun olduğuna karar verilmiştir. Araştırma ölçeğinin hazırlanmasında Petrick 'in (2002) çalışmasında yer alan kalite değeri, duygusal değer, fiyat değeri, davranışsal değer ve şöhret değeri faktörlerinde yer alan ifadeler destinasyona uyarlanarak ölçeğe dahil edilmiştir. Bu beş faktöre ilaveten Bu beş faktöre ilaveten Petrick 'in (2002) ölçeğinde yer yer almayan Sanchez ve diğ. (2006) tarafindan geliştirilen Gloval ölçeğinin boyutlarından birisi olan sosyal değer boyutu destinasyonların değer yaratma unsurlarından birisi olabileceği düşünülerek ölçeğe dahil edilmiştir. Ayrıca son olarak araştırma kapsamında incelenen algılanan değer ölçeklerinde yer almayan ancak destinasyon için önemli bir değer unsuru olabileceği düşünülen ve ulaşım değeri olarak adlandırdığımız ulaşım değeri faktörü tarafımızdan ölçeğe ilave edilerek çalışmada kullanılan algılanan değer ölçeği oluşturulmuştur. Tüketicilerin değer algılamalarına yönelik ifadeler beş noktalı (1: Hiç Katılmıyorum ile 5: Kesinlikle Katılıyorum) Likert tipi ölçek ifadeleriden oluşmaktadır. Yazıcıglu ve Erdoğan'a (2004:50) göre, $a=0.05$ ve \pm 0.05 örnekleme hataları için 10.000 .000 ve üstü evren büyüklüklerinde 384 örneklem sayısı yeterlidir. Buradan hareketle 600 adet anket formu çoğaltılmış ve Kemer İlçesinin Tekirova, Göynük ve Çamyuva beldelerinde bulunan turizm işletmelerinde tatillerini geçiren ve kolayda örnekleme yöntemiyle belirlenen ziyaretçiler üzerinde uygulanmıştır. Ziyaretçilerin seçiminde havayolunu kullanarak bölgeye ulaşım sağlamış olanlar tercih edilmiştir. Anket formları içerisinde yanlış ya da eksik doldurulan formlar analiz kapsamına dâhil edilmemiştir. Sonuç olarak 414 anket formu analizde kullanılmış ve bu formlardan elde edilen verilere dayanarak analizler gerçekleştirilmiştir. Verilerin analizinde ilk aşamada, ölçeğe açıklayıcı faktör analizi uygulanmış ve faktör yapıları belirlenmiştir. Açıklayıcı faktör analizi sonrasında ölçeğe doğrulayıcı faktör analizi uygulanmış ve ölçeğin yapısal geçerliliğini belirlemek için ayrışma, benzeşim ve iyilik uyum değerleri incelenmiştir. Ölçeğin yapısal geçerliliğinin belirlenmesinde ki-kare/serbestlik derecesi oranı, uyum iyiliği indeksleri, ayrışma ve benzeşim geçerlilik değerleri kullanılmıştır. Demografik değişkenlerin değerlendirilmesinde ise frekans ve yüzdelerden yararlanılmıştır. Araştırmada kullanılan algılanan değer ölçeği Tablo 3'de sunulmuştur. 
Tablo 3. Araştırmada Kullanılan Algılanan Değer Ölçeği

\begin{tabular}{|c|c|}
\hline \multicolumn{2}{|l|}{ Sosyal Değer (4 ifade) } \\
\hline $\begin{array}{l}\text { Destinasyonda tatil yapmış olmak } \\
\text { benimle ilgili algılamaları olumlu } \\
\text { etkileyecektir } \\
\text { Tanıdığım birçok kişi bu destinasyonda } \\
\text { tatil yapmıstır } \\
\text { Bu destinasyonda tatil yapmam } \\
\text { başkalarının benim hakkımdaki } \\
\text { düşüncelerini değiştirecektir } \\
\text { Destinasyonda tatil yapan turistler sosyal } \\
\text { bir onay almaktadırlar }\end{array}$ & $\begin{array}{l}\text { Sanchez ve } \\
\text { diğ., (2006) }\end{array}$ \\
\hline Kalite Değeri (4 ifade) & \\
\hline $\begin{array}{l}\text { Destinasyonda yüksek kalitede hizmet } \\
\text { sunulmaktadır } \\
\text { Destinasyon oldukça güvenlidir } \\
\text { Destinasyondaki işletmeler, çalışanlar ve } \\
\text { yerel halk güvenilirdir } \\
\text { Destinasyonda sunulan hizmetler vaat } \\
\text { edilenlerle tutarlıdır }\end{array}$ & $\begin{array}{l}\text { Petrick, } \\
(2002)\end{array}$ \\
\hline
\end{tabular}

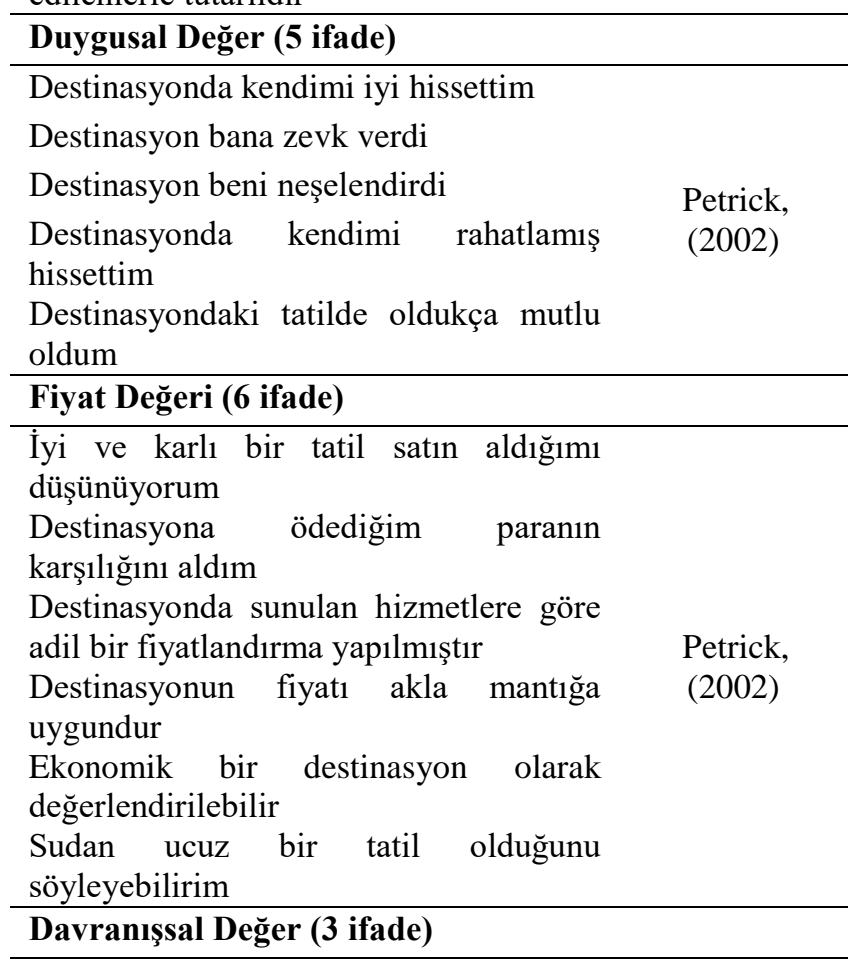

\begin{tabular}{lc}
\hline $\begin{array}{l}\text { Tatili satın almak kolay oldu } \\
\text { Tatili satın almak için az enerji harcadım }\end{array}$ & $\begin{array}{c}\text { Petrick, } \\
\text { (2002) }\end{array}$ \\
$\begin{array}{l}\text { Destinasyona ulaşmak için az enerji } \\
\text { harcadım }\end{array}$ & \\
\hline Şöhret değeri (5 ifade) & \\
\hline $\begin{array}{l}\text { Destinasyon iyi bir ünvana sahiptir } \\
\text { Saygı duyulan bir destinasyondur }\end{array}$ & \\
$\begin{array}{l}\text { Diğer destinasyonlar arasında iyi bir } \\
\text { destinasyon olduğu düşünülür }\end{array}$ & Petrick, \\
$\begin{array}{l}\text { Diğer destinasyonlar arasında belirli bir } \\
\text { statüye sahiptir }\end{array}$ & (2002) \\
$\begin{array}{l}\text { Diğer destinasyonlar arasında ünlü bir } \\
\text { destinasyondur }\end{array}$ & \\
\hline Ulaşım Değeri (2 ifade) & Ilave \\
\hline $\begin{array}{l}\text { Havaalanındaki işlemler hızlı ve çabuk } \\
\text { gerçekleşti }\end{array}$ & edilmiştir \\
\hline Transfer hızlı ve çabuk gerçekleşti & \\
\hline
\end{tabular}

$\mathrm{Bu}$ araștırmada Algılanan değer ölçeği yedi boyuttan oluşmaktadır. Petrick 'in (2002) algılanan değer ölçeğinde yer alan beş boyut (kalite değeri, fiyat değeri, duygusal değer, davranışsal ve şöhret değeri), Sanchez ve diğerleri (2006) tarafindan geliştirilen ölçekte yer alan bir boyut (sosyal değer) ve destinasyonlar için önemli bir değer yaratan faktör olabileceği düşünülen bir boyut (ulaşım değeri) ile birlikte çalışmanın destinasyon değeri ölçeği oluşturulmuştur.

\section{Araştırmanın Bulguları}

\subsection{Araştırma Katılımcılarının Demografik Özellikleri}

Araştırmaya katılan 414 kişinin \% 52,4’ü erkeklerden, \% 47,6'sı ise kadın katılımcılardan oluşturmaktadır. Katılımcıların \%26,3'ü 55 yaş ve üstü, \% 24,6'sı 25-34 yas arası, \%23,4'ü 35-44 yas arası, \% 16,4'ü 45-54 yas aras1 ve $\%$ 9,2'si 16-24 yas arasidır. Lisans derecesine sahip katılımcıların payı \% 58,7'dir. Lisans derecesine sahip olanları sırası ile 99 kişi ile ortaöğretim eğitim seviyesine sahip olanlar $(\% 23,9), 49$ kişi ile ilköğretim eğitim seviyesine sahip olanlar $(\% 11,8)$ ve 21 kişi ile lisansüstü dereceye sahip olanlar $(\% 5,1)$ izlemektedir. Son sırada ise 2 kişi ve $\% 0,5$ oranla herhangi bir eğitim almamış kişiler yer almaktadır. Katılımcıların \% 22,9'u işçi, \% 19,6 'sı memur, $\%$ 15,9'u emekli, \%12,3'ü ev hanımı, \% 10,6's1 esnaf, \% 9,4'ü ise ögrrenci ve \% 4,6 oranla tacir ve akademisyendir. Son olarak araştırma katılımcılarının \% 53,6'sı Bağımsız Devletler Topluluğundan, \% 25,8'i Türkiye Cumhuriyeti vatandaşlarından ve \% 20,6'sıda Alman vatandaşlarından oluşmaktadır.

\subsection{Algılanan Değer Ölçeğine Yönelik Açıklayıcı Faktör Analizi Sonuçları}

Öncelikle verilerin faktör analizine uygunluğunu test etmek için normal dağılım testi yapılmıştır. Dağılım için hesaplanan çarpıklık katsayısı (skewness) -0.228, basıklık katsayısı (kurtosis) ise -0.154 'dır. Bu bulguya göre verilerin çarpıklığ1 ve basıklığ1 0.05 anlam seviyesinde ideal değerler arasındadır. Algılanan değer ölçeğine yönelik gerçekleştirilen güvenilirlilik analizi sonucunda ölçeğin Cronbach alfa değerinin 0,93 olduğu görülmüştür. Düzeltme indeksleri incelenmiş ve herhangi bir düzeltmeye gerek duyulmamıştır. Bu haliyle ölçeğin güvenilirliği 1'e oldukça yakın ve yüksek bir güvenilirlilik yüzdesine sahiptir. Çalışmada ele alınan örneklemin sayısı (414 adet) dikkate alındığında, 0,05 anlamlılık düzeyinde bir sonuca ulaşmak için, faktör ağırlığı veya faktör yükü katsayılarının 0,4 'ten küçük olmaması gerekmektedir. Bu nedenle, mutlak değeri 0,4'ten küçük olan faktör yüklerine analiz sonuç tablolarında yer verilmemiştir. Araştırmada uygulanan faktör analizi sonuçlarına göre; Temel Bileşenler Analizinde, Kaiser Meyer Olkin (KMO) değeri 0.88 bulunmuştur. KMO testi, dağılımın faktör analizi için yeterli olup olmadığını test etmektedir ve $0.80-0.90$ aralığı çok iyi olarak değerlendirilmektedir (Akgül ve diğ., 2003). Dolayısıyla bu çalışmadaki KMO değerinin çok iyi düzeyde olduğu söylenebilir. Barlett testi sonucu 708,003 $(\mathrm{p}<0.05)$ olarak tespit edilmiştir. $\mathrm{Bu}$ bulgu ölçüm yaptığımız değişkenin evren parametresinde çok değişkenli olduğunu göstermektedir. Her iki test sonucuna bakıldığında, ölçeğe faktör analizi yapılmasının uygun olacağı görülmüştür. 
Tablo 4. Algılanan Değer Ölçeğine Yönelik Açıklayıcı Faktör Analizi Sonuçları

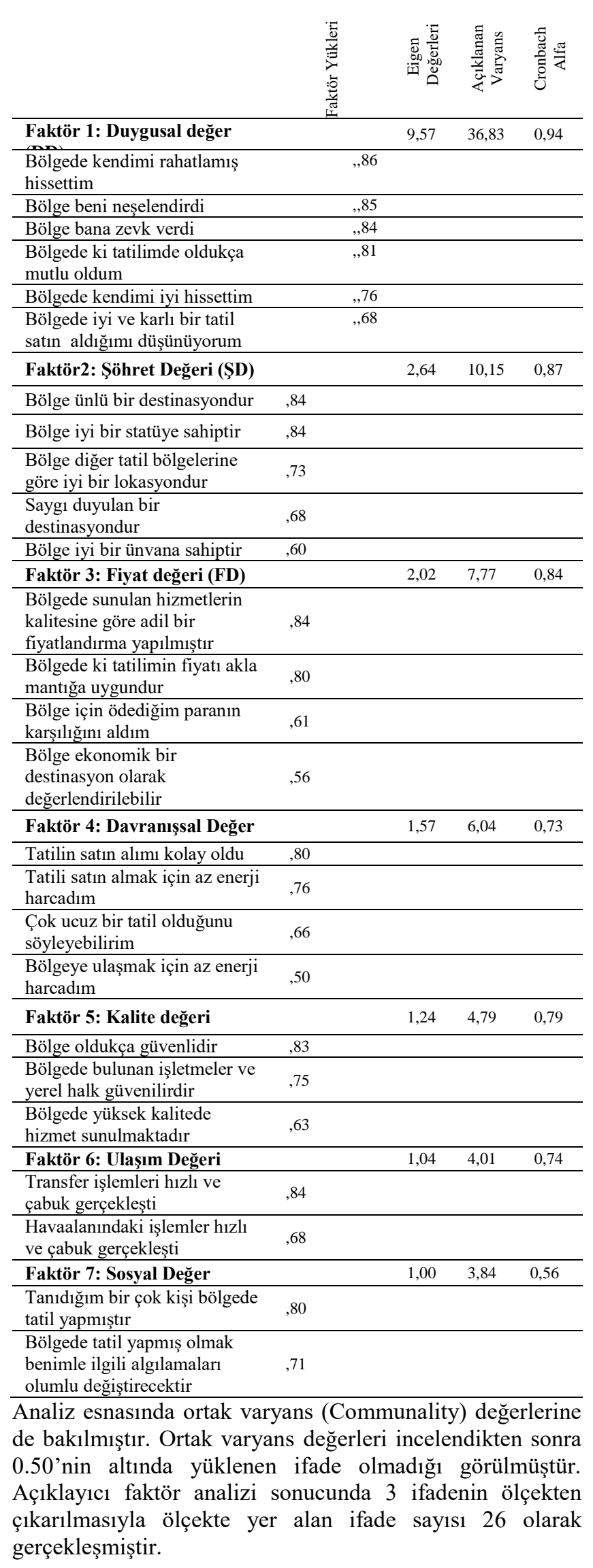

Açıklayıcı faktör analizinin yapılma nedeni, çok fazla sayıdaki ifadeyi az sayıda faktöre düşürmektir. Açıklayıcı faktör analizi sonucunda elde edilen boyutlara bir ad vermek gerekir. $\mathrm{Bu}$ ad, faktörü oluşturan değişkenlerin yapısına bakılarak verilebilir (Yavuz, 2007). Faktör analizi sonucunda ölçeğe ilişkin 26 değişken 7 boyuta indirgenmiş ve her bir faktör değişkenlerin yapısı ve alan yazındaki kullanımları dikkate alınarak isimlendirilmiştir. Faktör analizi sonucunda destinasyondan algılanan değer ölçeğinin çok boyutlu yapıda ve duygusal değer, fiyat değeri, şöhret değeri, davranışsal değer, kalite değeri, ulaşım değeri ve sosyal değer olmak üzere yedi boyuttan oluştuğu tespit edilmiştir.

\subsection{Algılanan Değer Ölçeğine Yönelik Doğrulayıcı Faktör Analizi Sonuçları}

Çalışmanın bu bölümünde araştırmada kullanılan algılanan değer ölçeğine yönelik doğrulayıcı faktör analizi uygulanmıştır. Analiz sürecinde öncelikle uyum iyiliği değerleri değerlendirilmeye alınmıştır. Düşük faktör yüküne $(X<0.50)$ ve düşük $t$ değerine sahip $(X<1,96)$ gözlemlenen değişkenler ölçekten çıkarılmıştır. Ayrıca açıklayıcı faktör analizi sonucunda iki ifadeden oluşan sosyal değer boyutunu oluşturan ifadelerden birisi doğrulayıcı faktör analizi sonucunda düşük standart yüke sahip olması nedeniyle ölçekten çıkarılmış, sosyal değer faktörünü temsil eden ifade sayısı bire düşmüş ve tek değişkenin faktör oluşturamaması nedeniyle sosyal değer faktörü Dfa sonucunda ölçekten çıkarılmıştır. Bu nedenle açıklayıcı faktör analizi sonucunda yedi faktörden meydana gelen algılanan değer ölçeği doğrulayıcı faktör analizi sonucunda altı faktöre düşmüştür. Gerekli düzeltme ve modifikasyon işlemlerinin gerçekleştirilmesi sonucunda yeterli değerlere ulaşılmıştır. Tablo 5'te algılanan değer ölçeğine ait iyilik uyum değerleri yer almaktadir.

Tablo 5. Algılanan Değer Ölçeğine Yönelik İyilik Uyum Değerleri

\begin{tabular}{|c|c|c|c|c|c|c|c|c|c|}
\hline$\chi^{2}$ & $\begin{array}{l}x^{2} \\
/ \mathrm{df}\end{array}$ & $\underset{\mathbf{A}}{\text { RMSE }}$ & $\begin{array}{c}\text { SRM } \\
\text { R }\end{array}$ & $\begin{array}{c}\text { GF } \\
\text { I }\end{array}$ & $\underset{\mathbf{I}}{\mathbf{A G F}}$ & NFI & $\begin{array}{c}\text { NNF } \\
\text { I }\end{array}$ & $\begin{array}{c}\text { CF } \\
\text { I }\end{array}$ & RFI \\
\hline & $\leq 5$ & $<0.08$ & $<0.10$ & $\begin{array}{l}\geq .9 \\
0\end{array}$ & $>0.80$ & $\begin{array}{c}>0.9 \\
0\end{array}$ & $\geq 0.90$ & $\begin{array}{c}\geq .9 \\
0\end{array}$ & $\begin{array}{r}\geq .8 \\
5\end{array}$ \\
\hline $\begin{array}{c}350,2 \\
3\end{array}$ & $\begin{array}{c}3,9 \\
3\end{array}$ & 0,08 & 0,06 & $\begin{array}{c}0,9 \\
0\end{array}$ & 0,85 & 0,91 & 0,90 & $\begin{array}{c}0,9 \\
3\end{array}$ & $\begin{array}{c}0,8 \\
7\end{array}$ \\
\hline
\end{tabular}

Tablo 5'te modelin eldeki veriye uygunluğunu gösteren 9 farklı uyum değeri yer almaktadır. Ölçüm modeli endekslerine göre, $\chi 2$ değerinin serbestlik derecesine oranı 3,9'dur ve iyi düzeyde uyum olduğunu göstermektedir. RMSEA değeri 0,8'dir. GFI değeri 0,90 ile kabul edilebilir bir değere sahiptir. Analiz sonucunda uyum iyiliği indeks değerleri kabul edilebilir düzeydedir. Yeterli uyum iyiliği değerlerine ulaşıldıktan sonra ölçeğe doğrulayıcı faktör analizi uygulanmıştır. Doğrulayıcı faktör analizinde yapısal geçerliliği tespit etmek için yakınsak(benzeşim) ve iraksak (ayrışım) geçerliliğinin sağlanması gerekmektedir. Yakınsak geçerliliğinin analizi için, modeli oluşturan faktörlerin bileşik güvenilirlik katsayıları (CR) ve açıklanan ortalama varyans değerleri (AVE) hesaplanmaktadır. Yakınsak geçerliliğin sağlanması için; faktörlerin açıklanan ortalama varyans değerlerinin 0.50 değerinin üzerinde ve bileşik güvenilirlik katsayılarının 0.70 değerinin üzerinde olması gerekmektedir (Fornell ve Larcker, 1981). CR değerlerin 0.70 değerinin üzerinde olması, faktörlerin içsel tutarlılığının yüksek olduğuna; AVE değerlerinin 0.50 değerinin üzerinde 
olması ise, faktörlerle ilişkili olan değişkenler tarafından yeterli düzeyde varyans açıklandığına işaret etmektedir. bileşik güvenilirlik ve çıkarılan ortalama varyansın hesaplanması aşağıdaki gibi formüle edilmektedir.

$$
\begin{aligned}
& \text { Bileşik güvenilirlik }(\text { CR }) \\
& =\frac{(\text { EFaktör yükleri }) 2}{\left[\left(\sum \text { Faktör yükleri }\right) 2+\sum \text { Hata katsay } \square \text { lar } \square\right]} \\
& C \zeta \square \text { kar } \square \text { lan Ort.Varyans }(\text { AVE }) \\
& =\frac{\sum(\text { Faktör yükleri }) 2}{\left[\sum(\text { Faktör yükleri }) 2+\sum \text { Hata katsay } \square \text { lar } \square\right]}
\end{aligned}
$$

Yapısal geçerliliğin sağlanmasında ikinci unsur ayrışma geçerliliğinin sağlanmasıdır. Ayrışma geçerliliğin sağlanması için iki farklı yaklaşım uygulanmaktadır. Bunlardan ilki faktörler arasındaki korelasyon değerlerine bakılmasıdır. Faktörler arası korelasyon değerlerinin 0.85 'ten küçük olması ayrışma geçerliliğinin bir göstergesi olarak değerlendirilmektedir (Klein, 2000). İkinci yaklaşım ise bir faktöre ait ortalama açıklanan varyans değerinin (AVE) karekökünün $(\sqrt{A V E})$, bu faktörün diğer faktörlerle olan korelasyon değerlerinden büyük olmasıdır. (Fornell ve Larcker, 1981). Eğer hem yakınsaklık hem de ayrışma geçerliliği kriterleri sağlanıyor ise, modelin yapısal olarak geçerli olduğuna karar verilmektedir. Algilanan değer ölçeğinin doğrulayıcı faktör analizi ve yakınsak geçerliliğine ilişkin analiz sonuçları Tablo 6'da sunulmaktadır.

\begin{tabular}{|c|c|c|c|c|c|}
\hline Gizil Değişkenler & 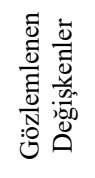 & 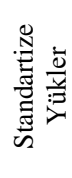 & 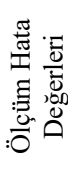 & 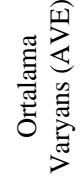 & 菢剪 \\
\hline \multirow{3}{*}{ Duygusal Değer (Hİ) } & DD1 & 1.0 & 0.2 & \multirow{3}{*}{0.80} & \multirow{3}{*}{0.92} \\
\hline & DD2 & 0.9 & 0.1 & & \\
\hline & DD3 & 0.9 & 0.3 & & \\
\hline \multirow{3}{*}{ Şöhret Değeri (ŞD) } & ŞD1 & 0.7 & 0.4 & \multirow{3}{*}{0.71} & \multirow{3}{*}{0.87} \\
\hline & ŞD2 & 0.9 & 0.3 & & \\
\hline & ŞD3 & 0.9 & 0.2 & & \\
\hline \multirow{3}{*}{ Fiyat Değeri(FD) } & FD1 & 0.7 & 0.5 & \multirow{3}{*}{0.67} & \multirow{3}{*}{0.85} \\
\hline & FD2 & 0.8 & 0.2 & & \\
\hline & FD3 & 0.8 & 0.2 & & \\
\hline \multirow{3}{*}{$\begin{array}{l}\text { Davranışsal Değer } \\
\text { (DVD) }\end{array}$} & DVD & 0.6 & 0.3 & \multirow{3}{*}{0.50} & \multirow{3}{*}{0.74} \\
\hline & DVD & 0.8 & 0.2 & & \\
\hline & DVD & 0.5 & 1.0 & & \\
\hline \multirow[t]{2}{*}{ Kalite Değeri (KD) } & KD1 & 0.7 & 0.4 & \multirow[t]{2}{*}{0.63} & \multirow[t]{2}{*}{0.77} \\
\hline & KD2 & 0.8 & 0.2 & & \\
\hline \multirow{2}{*}{$\begin{array}{l}\text { Ulaşım Değeri } \\
\text { (ULD) }\end{array}$} & ULD & 0.7 & 0.3 & \multirow{2}{*}{0.60} & \multirow{2}{*}{0.75} \\
\hline & ULD & 0.6 & 0.3 & & \\
\hline
\end{tabular}

Tablo 6. Doğrulayıcı Faktör Analizi Sonuçları ve Ölçeğin Yapısal Geçerliliği

Tablo 6'da görüldüğü üzere algılanan değeri oluşturan bilişsel ve duygusal imaj faktörlerinin bileşik güvenilirlik değerleri (CR) tümü 0.70 üstünde bir değere sahiptir. Ave değerleri, kritik değer olan \%50'nin üstündedir. En yüksek AVE değerine sahip faktör duygusal değerdir $(0,80)$. Şöhret değeri 0,71 , fiyat değeri 0,67 , davranıșsal değer 0,50 , kalite değeri 0,63 ve son olarak ulaşım değeri 0,63 ortalama varyans değerine sahiptir.

Ölçeğin yapısal geçerliliği ile ilgili bir diğer kıstas, ayrışma geçerliliğinin oluşmasıdır. Algılanan değer ölçeği 6 boyuttan oluşmaktadır. Ölçeği oluşturan tüm boyutlar arasındaki korelasyon değerlerinin 0,850'den küçük olması modeldeki boyutların ayrı yapılar olduğunu ve ayrışma geçerliliğinin sağlandığının ilk göstergesidir.

\begin{tabular}{|c|c|c|c|c|c|c|}
\hline & 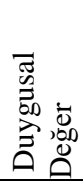 & 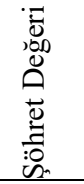 & 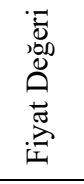 & 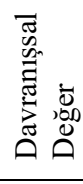 & 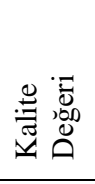 & 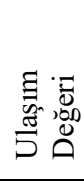 \\
\hline $\begin{array}{l}\text { Duygusal } \\
\text { Değer }\end{array}$ & $\begin{array}{c}(0,894 \\
)\end{array}$ & & & & & \\
\hline $\begin{array}{l}\text { Şöhret } \\
\text { Değeri }\end{array}$ & 0,495 & $\begin{array}{c}(\mathbf{0 , 8 4 2} \\
)\end{array}$ & & & & \\
\hline $\begin{array}{l}\text { Fiyat } \\
\text { Değeri }\end{array}$ & 0,495 & 0,389 & $\begin{array}{c}(\mathbf{0 , 8 1 8} \\
)\end{array}$ & & & \\
\hline $\begin{array}{l}\text { Davranışsa } \\
1 \text { Değer }\end{array}$ & 0,254 & 0,143 & 0,406 & $\begin{array}{c}(0,707 \\
)\end{array}$ & & \\
\hline $\begin{array}{l}\text { Kalite } \\
\text { Değeri }\end{array}$ & 0,522 & 0,394 & 0,552 & 0,310 & $\begin{array}{c}(0,793 \\
)\end{array}$ & \\
\hline $\begin{array}{l}\text { Ulaşıı } \\
\text { Değeri }\end{array}$ & 0,360 & 0,446 & 0,349 & 0,469 & 0,271 & $\begin{array}{c}(0,774 \\
)\end{array}$ \\
\hline
\end{tabular}

Tablo 7. Faktörlere Yönelik DFA Sonuçlarına Göre Ölçeğin Ayrışma Geçerliliği

Modelin ayrışma geçerliliğinin tespitinde kullanılan ikinci yaklaşım her bir faktöre ait AVE değerinin karekökünün faktörler arası korelasyon değerlerinden yüksek olmasıdır. Tablo 7'de her bir faktörün sahip olduğu AVE değerinin karekökleri kalın punto ile gösterilmiştir. Tablo 7'ye göre tüm faktörler arasındaki korelasyon değeri her bir faktöre ait AVE değerlerinin kareköklerinden küçüktür. Bu rakamlar modeldeki boyutların ayrı yapılar olduğu ve ayırma geçerliliğinin sağlandığının ikinci göstergesidir.

\section{Sonuç ve Öneriler}

Araştırma da algılanan değer ölçeğine uygulanan açıklayıcı faktör analizi sonucunda katılımcılar tarafından bir boyut olarak desteklenen sosyal değer boyutu, ölçeğe daha sonra gerçekleştirilen doğrulayıcı faktör analizi sonucunda gözlenen değişkenlerin yeterli yük ile gizlenen değişkenlere (boyut) yüklenmemelerinden dolayı ölçekten çıkarılmıştır. Sonuç olarak araştırmada kullanılan toplam yedi boyut ve 29 ifadeden oluşan araştırma ölçeği açıklayıcı ve doğrulayıcı faktör analizleri sonucunda 16 ifadeden oluşan toplam 6 boyut olarak gerçekleşmiştir.

Araştırma sonucunda elde edilen bulgulara göre algılanan değer ölçeğini oluşturan ilk boyut duygusal değer boyutudur. Duygusal değer boyutu turistin tatilini geçirdiği destinasyonun kendisinde uyandırmış olduğu duyguları ifade etmektedir. Çalışmada duygusal değer boyutunun alındığı Petrick'in (2002) çalışmasında yer alan ifadelerin bu çalışmada da bir araya toplandığ 1 görülmektedir. Duygusal değer boyutunun ilk olarak Sheth ve diğerleri (1991) 
tarafından önerildiği daha sonra Perval, Serv-Perval ve Gloval ölçeklerinde de ele alındığı görülmektedir. Çalışmada algılanan değer ölçeğinde yer alan ikinci boyut şöhret (ün) değeri boyutudur. Şöhret değeri destinasyonun diğer alternatif destinasyonlara göre tanınırlılığının turistler tarafından algılanma biçimidir. Turistler tatil için destinasyon seçimlerinde destinasyonun şöhreti, ünü ve bilinilirliği ile de ilgilenmektedirler. Şöhret değeri boyutu

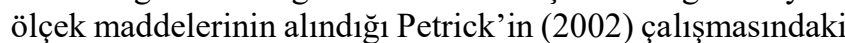
gibi tek bir faktörde toplanmış ve destinasyonlar için uygulanabilirliği tespit edilmiştir. Araştırmada tespit edilen üçüncü faktör fiyat değeri faktörüdür. Fiyat değeri katlanılan maliyetler karşısında elde edilen mal ve hizmet değerlendirmeleri olarak ifade edilebilir. $\mathrm{Bu}$ durum ilk olarak Zeithaml (1988) tarafindan ileri sürülmüş daha sonra Sweeney ve Soutar (2001) bu boyuta Fonksiyonel Değer 2 ismini vermiştir. Bu iki çalışmada fiyat bazlı değer faktörünün Sweeney ve Soutar (2001) tarafindan önerilen "paranın karşılığında değer" adlı faktörle benzerlik gösterdiği görülmektedir. Bir başka çalışmada Petrick (2002) restoran hizmetlerine yönelik algılanan değerin katlanılan maliyetlerini maddi ve davranışsal fiyat olarak ikiye ayırmıştır. Fiyat bazlı değer boyutunun ifadeleri Petrick'in (2002) ölçeğindeki parasal fiyat faktöründe, Sanchez ve diğerlerinin (2006) çalışmasında ise, "fiyatın fonksiyonel değeri" adlı faktör altında yer aldığı görülmektedir. Ölçekte fiyat değeri boyutunda yer alan ifadeler "bölgede sunulan hizmetlerin kalitesine göre adil bir fiyatlandırma yapılmıştır", "bölgedeki tatil için ödediğim paranın karşılığını aldım" ve son olarak "bölge ekonomik bir destinasyon olarak değerlendirilebilir" ifadeleridir. Fiyat boyutunun alındığ 1 Petrick'in (2002) çalışmasında 6 ifadeden oluşan boyut çalışmada 3 ifadeli bir boyut olarak gerçekleşmiştir. Çalışmada algılanan değer ölçeğinde yer alan bir diğer boyut davranışsal değer boyutudur. Davranışsal değer kavramı tatilin satın alımı, satın alım esnasında harcanan enerji ve tatil bölgesine ulaşmak için harcanan zaman ile ilgili faaliyetlerden ortaya çıkan boyut olarak ifade edilebilir. Turistlerin ürünleri değerlendirirken sadece ürünlerin parasal değerlerini dikkate almadıkları, ürünü satın almak için harcadığı zaman ve enerjiyi de değerlendirdikleri görülmektedir. Petrick'in (2002) davranışsal değer boyutunda yer verdiği ürünün satın alımı esnasında az enerji harcama, kolay bir satın alım gerçekleştirebilme ve az çaba sarf etme ifadeleri bu çalışmadada aynı şekilde davranışsal değer boyutunda yer almaktadır. Çalışmada algılanan değer ölçeğinde yer alan bir diğer boyut kalite değeri boyutudur. Destinasyonda sunulan hizmetlerin kalite düzeyi, destinasyonun kendisinin, destinasyonda yaşayan yerel halkın ve çalışanların güvenilirliği ve zaman içerisinde verilen hizmet kalitesindeki tutarlılığı içermektedir. Kalite boyutunun algılanan değerin şekillenmesindeki en önemli unsurlardan birisi olduğu söylenebilir (Zeithaml, 1988). Algılanan değerin ölçümüne yönelik geliştirilen ölçeklerin tamamında kalite boyutu yer almakta ve özellikle de yazarlar tarafindan algılanan değerin şekillenmesinde kalitenin önemli bir rol oynadığı belirtilmektedir. İlk olarak Zeithalm (1988) tarafindan algılanan değer boyutu olarak tanımlanan kalite boyutu, daha sonra Sheth ve diğerleri (1991) tarafindan ürün ya da hizmetin faydası olarak fonksiyonel değer adı altında değerlendirilmiştir. Sweeney ve Soutar (2001) fonksiyonel değeri iki alt boyutta değerlendirmiş ve ürünlerin kalitesini temsil eden ifadeleri "fonksiyonel değer I kalite/performans" boyutu altında toplamıștır. Petrick (2002), Sweeney ve Soutar (2001)'ın çalışmasında olduğu gibi kalite boyutunu hizmete yönelik algılanan değerin bir boyutu olarak değerlendirmiştir. Alan yazında ölçeklerin kalite boyutunun açıklanmasına yönelik ortak ifadeler incelendiğinde, ürün ya da hizmet kalitesinin yüksek kalite, güvenilirlik ve tutarlılık ile ölçüldüğü görülmektedir. Turistik destinasyon ölçeğinde gerçekleştirilen bu çalışma sonuçlarına göre de kalite değeri destinasyon algılanan değer ölçeğini oluşturan önemli bir faktördür. Çalışmada algılanan değer ölçeğinde yer alan son boyut literatürdeki çok boyutlu ölçeklerde yer almayan ancak turizm destinasyonları için önemli olduğu düşünülen ulaşım değeri boyutudur. Turizme özgü dağıtım kanalının ters yönlü işlemesi daha açık bir ifadeyle turistin tatili satın almak için hizmetin üretildiği destinasyona gitmek zorunda olması nedeniyle bir turist için ulaşımda harcanan emek ve zaman oldukça önemli bir unsur olarak karşımıza çıkmaktadır. Bir turist için en önemli faktörlerden bir tanesi evden çıktıktan sonra en kısa sürede tatilini geçireceği bölgeye ulaşmaktır. Bu durumun en önemli göstergelerinden birisi dünyada turist çeken ülkelerin en fazla turisti kendisine yakın bölgelerden almasıdır. Ayrıca günümüzde havayolundaki gelişmelere paralel olarak havaalanı ve transfer işlemleri hızlanmış ancak her destinasyon için aynı standart yakalanamamıştır. Dolayısıyla ulaşım değeri olarak isimlendirdiğimiz faktör, özellikle destinasyonlar için değer yaratmada ve rekabet avantajı sağlamada önemli bir özelliktir. Bu nedenle Petrick (2002) ile Sanchez ve diğerlerinin (2006) ölçeklerinde yer almayan ancak destinasyon bağlamında önemli bir faktör olabileceğini düşünerek ölçeğe dahil ettiğimiz "havaalanındaki işlemler hızlı ve çabuk gerçekleşti" ve "transfer işlemleri hızlı ve çabuk gerçekleşti” ifadeleri tek bir faktör altında toplanmış ve faktörü oluşturan ifadeler dikkate alındığında ortaya çıkan yeni faktörün ulaşım değeri olarak isimlendirilmesi düşünülmüştür. Araştırmada ilk olarak Sheth ve diğerleri (1991) tarafindan çok boyutlu algılanan değer ölçeğinde bir boyut olarak değerlendirilen ve Sanchez ve diğerlerinin (2006) seyahat acentaları faaliyetlerine yönelik gerçekleştirdiği çalışmasında yer alan "sosyal değer" boyutu destinasyon ölçeğinde gerçekleştirilen bu çalışma sonuçlarıyla desteklenmemiş ve sosyal değerin uygulanabilirliği çalışma örneklemi kapsamında kanıtlanamamıştır.

Araştırmanın ortaya koyduğu sonuçlardan yararlanarak, yerel yönetimler, turizm işletmeleri ve turizm ile ilgili STK'lar için çeşitli öneriler geliştirilmiştir. Araştırma sonucunda elde edilen 6 farklı değer boyutu destinasyon için önem arz etmektedir. Destinasyonda turistler için değer yarattığı tespit edilen şöhret ve kalite değerini arttırıcı faaliyetler gerçekleştirilebilir. Trivago isimli internet sitesinin 2014 yılının en iyi değere sahip destinasyonlara ait hazırlamış olduğu listede Fas'ın Ait Benhaddou şehri birinci sırada yer almaktadır. Fas'ın popular sembollerinden birisi olan ve savunma amaciyla kurulmuş bir kale kasabası olan bölge, "Gladiatör", "Kingdom of Heaven" ve "Game of Thrones" gibi dünyada yüksek gişe oranlarına sahip filmlerin çekilmesiyle birlikte ünlenmiştir. Bu sayede bir çok turist tarafından ziyaret edilmeye başlanmıştır. Ayrıca çalışmada algılanan değer ölçeğinde yer alan sosyal değer boyutu çalışma sonuçlarına göre ölçekten çıkarılmıştır. Destinasyonun turistlere sosyal bir ayrıcalık veya avantaj sağlamamasından dolayı turistler çalışmanın uygulandığı 
destinasyonda sosyal değer algılayamamaktadır. Sosyal değerin yaratılması için, tanınan ve bilinen kişilerin destinasyonda tatil yapmaları sağlanarak destinasyonun ismi kitle iletişim araçlarıyla duyurulabilir. Bununla birlikte destinasyonun tanıtımında ün ve şöhret sahibi kişiler kullanılarak destinasyonun kişilerde uyandırdığı sosyal değer algısı şekillendirilebilir.

$\mathrm{Bu}$ çalışmada turizm destinasyonundan algılanan değer ölçeği duygusal değer, fiyat değeri, şöhret değeri, davranışsal değer,sosyal değer, kalite değeri ve ulaşım değeri kavramlarından oluşturulan ölçek ile analiz edilmiştir. Araştırmaya çeşitli nedenlerle dâhil edilememiş farklı değişkenlerin kullanılması ve destinasyon boyutunda uygulaması yapılabilir.

\section{Kaynakça}

Akgül, A. ve Çevik, O. (2003), İstatistiksel Analiz Teknikleri “SPSS'te İşletme Yönetimi Uygulamaları, Ankara, Emek Ofset Ltd. Şti.

Cronin, J. J., Brady, M. K. ve Hult, G. M. (2000). Assessing the Effects of Quality, Value, and Customer Satisfaction on Consumer Behavioral Intentions in Service Environments", , Vol.76, No.2, 193-218. Journal of Retailing , 76 (2), 193-218.

Day, G. S. (1990). Market Driven Strategy. New York: Free Press.

De Ruyter, J. K., Wetzels, M., Lemmink, J. ve Mattson, J. (1997). The Dynamics of The Service Delivery Process: A Value-Based Approach. International Journal of Research in Marketing , 14, 231-243.

Dodds, W. B., Monroe, K. B. ve Grewal, D. (1991). Effects of Price,Brand and Store Information on Buyers' Product Evaluations. Journal of Marketing Research , 28, 307319.

Fernandez, R. S. ve Bonillo, A. I. (2007). The Concept of Perceived Value: A Systematic Review of The Research. Marketing Theory, 7, 427-451.

Fornell, C. ve Larcker, D. (1981). Evaluating Structural Equation Models with Unobservable Variables and Measurement Error. Journal of Marketing Research , 18, 39-50.

Gale, B. T. (1994). Managing Customer Value: Creating Quality And Service That Customers Can See. New York: Free Press.

Gallarza, M. G. ve Saura, I. G. (2006). Value Dimensions, Perceived Value, Satisfaction and Loyalty: An Investigation of University Students' Travel Behavior. Tourism Management, 27, 437-452.

Gill, D., Byslma, B. ve Ouschan, R. (2007). Customer Perceived Value in A Cellar Door Visit: The Impact on Behavioural Intentions. International Journal of Wine Business Research , 19 (4), 257-275.

Grewal, D., Krishnan, R., Baker, J. ve Borin, N. (1998). The Effect of Store Name, Brand Name and Price Discounts on Consumers' Evaluations and Purchase Intentions. Journal of Retailing , 74 (3), 331-352.
Gronroos, C. (1997). Value-Driven Relational Marketing: From Products To Resources And Competencies. Journal of Marketing Management, 13 (5), 407-420.

Holbrook, M. B. (1996). Customer Value-A Framework for Analysis and Research. Advances in Consumer Research , 23, 138-142.

Katamneni, S. P. ve Coulson, K. R. (1996). Measuring Perceived Value: Findings from Preliminary Research. The Journal of Marketing Management , 2, 72-86.

Kline, R. B. (1998). Principles and Practice of Structural Equation Modeling. NY: Guilford Press.

Koçak, G. N. ve Çeşmeci, N. (2011). Altın Çöpe Düşse Değerini Kaybeder Mi, Tenekeyi Parlatsan Çeyrek Altın Eder Mi? Algılanan Değer Ölçekleri, Altın M1-Teneke Mi? Geçerlilik ve Güvenilirlik Tartışması. 12. Ulusal Turizm Kongresi. Akçakoca- DÜZCE: 30 Kasım - 4 Aralik 2011.

Konuk, F. A. (2008). Pazarlamada Algılanan Değer Kavramı ve Ölçümü. Yayınlanmamış Doktora Tezi. Sakarya Üniversitesi Sosyal Bilimler Enstitüsü. Sakarya.

Lichtenstein, D. R., Netemeyer, R. G. ve Burton, S. (1990). Distinguishing Coupon Proneness from Value Consciousness: An Acquisition- Transaction Utility Theory Perspective. Journal of Marketing , 54, 54-67.

Monroe, K. B. (1990). Pricing: Making Profitable Decisions. New York: McGraw-Hill.

Petrick, J. F. (2002). Development of Multi-Dimensional Scale for Measuring the Perceived Value of a Sevice. Journal of Leisure Reseach , 34 (2), 119-134.

Petrick, J. F. (2004). First Timers' and Repeaters' Perceived Value. Journal of Travel Research , 43, 29-38.

Sanchez, J., Callarisa, L., Rodriguez, R. M. ve Moliner, M. A. (2006). Perceived Value of the Purchase of a Tourism Product. Tourism Management, 27, 394-409.

Sanchez-Fernandez, R. M., Iniesta-Bonillo, A. ve Holbrook, M. B. (2009). The Conceptualisation and Measurement of Consumer Value in Services. International Journal of Market Research , 51 (1), 93-113.

Sheth, J. N., Newman, B. I. ve Gross, L. G. (1991). Why We Buy What We Buy: A Theory of Consumption Values. Journal of Business Research , 22, 159-170.

Sin, L. Y., So, S. L., Yau, O. H. ve Kwong, K. (2001). Chinese Women at the Crossroads: An Ampirical Study on Their Role Orientations and Consumption Values in Chinese Society. Journal of Consumer Marketing , 18 (4), 348-367.

Smith, J. B. ve Colgate, M. (2007). Customer Value Cretaion: A Practical Framework. Journal of Marketing Theory and Practice, 15 (1), 7-23.

Sweeney, J. C., Soutar, G. N. ve Johnson, L. W. (1997). Retail Service Quality and Perceived Value. Journal of Retailing and Consumer Services , 4 (1), 39-48. 
Sweeney, J. C. ve Soutar, G. N. (2001). Consumer Perceived Value: The Development of a Multiple Item Scale. Journal of Retailing , 77, 203-220.

Woodruff, R. B. (1997). Customer Value: The Next Source for Competitive Advantage. Journal of the Academy of Marketing Science, 25 (2), 139-153.

Yavuz, M. C. (2007). Uluslararası Destinasyon Markası Oluşturulmasında Kimlik Geliştirme Süreci: Adana
Örneği. Yayınlanmamış Doktora Tezi. Çukurova Üniversitesi Sosyal Bilimler Enstitüsü. Adana.

Yazıcioglu, Y. ve Erdogan, S. (2004). Spss Uygulamalı Bilimsel Arastırma Yöntemleri. Ankara: Detay Yayıncilik.

Zeithaml, V. A. (1988). Consumer Perceptions of Price, Quality and Value: A Means-End Model and Synthesis of Evidence. Journal of Marketing , 52, 2-22. 
